\title{
Comparison of different standardized bond strength tests and the influence of glycine powder treatment in composite resin repairs
}

\section{Gregor Patrik Herrmann ${ }^{1} \bowtie$, Susanne Reimann ${ }^{2}{ }^{\circledR}$, Nikolaos Daratsianos ${ }^{3}$,

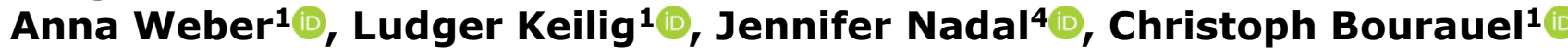

\author{
${ }^{1}$ University of Bonn, Oral Technology, Bonn, Germany \\ ${ }^{2}$ University of Applied Sciences Bremerhaven, Medical Engineering, Bremerhaven, Germany \\ ${ }^{3}$ University of Bonn, Department of Orthodontics, Bonn, Germany \\ ${ }^{4}$ University of Bonn, Institute for Medical Biometry, Informatics and Epidemiology, Bonn, Germany
}

\section{Correspondence:}

Dr. Gregor Patrik Herrmann University of Bonn, Oral Technology, Welschnonnenstr 17, 53111

Bonn, Germany

E-mail:bourauel@uni-bonn.de

Received: 13 September 2019 Accepted: 11 January 2020

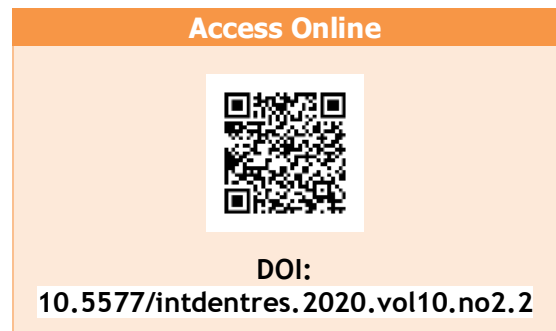

\section{Abstract}

Aim: The repair of restorations is an eligible method to extend the survival rates of intraoral restorations. There is a consensus that the old surface has to be removed before repair by the use of a sandblaster or rotating instruments. This study aimed to investigate whether a glycine powder can be used successfully in composite repair by measurement of shear and tensile bond strength according to dental standards.

Methodology: The influence of mechanical preparation by no powder, $25 \mu \mathrm{m}$ glycine powder or $50 \mu \mathrm{m}$ aluminium-oxide powder and chemical conditioning by the use of bonding, phosphoric acid and bonding or bonding, phosphoric acid and a silane on the repair bond strength of an artificially aged nano-hybrid composite was tested according to the guidelines of DIN 13990 (2017), ISO 29022 (2013) and ISO/TS 11405 (2015). The fracture modes were evaluated by adhesive, cohesive or mixed failures.

Results: There was no significant difference in the performance of the different mechanical and chemical treatments. The shear bond test according to DIN 13990 (2017) produces higher repair bond strengths $(26.0 \pm 8.9 \mathrm{MPa})$ than the test described in ISO $29022(17.9 \pm 6.3 \mathrm{MPa})$. The tensile bond strength according to ISO/TS $11405(6.9 \pm 1.8 \mathrm{MPa})$ was the lowest. Most adhesive failures occurred with the shear test according to ISO 29022 (41\%), followed by DIN $13990(18 \%)$ and the tensile test (4\%).

Conclusion: For evaluating the bond strength of composites the test described in ISO 29022 is recommended, because it produces the highest percentage of adhesive failures. Nano-hybrid-composites are robust to different repair protocols.

Keywords: Composite resin, repair, sandblasting, bond strength test.

How to cite this article: Herrmann GP, Reimann S, Daratsianos N, Weber A, Keilig L, Nadal J, Bourauel C. Comparison of different standardized bond strength tests and the influence of glycine powder treatment in composite resin repairs. Int Dent Res 2020;10(1):36-43. https://doi.org/10.5577/intdentres.2020.vol10.no2.2 


\section{Introduction}

Dental composites are commonly used for the restorations of lesions of oral hard tissues (1-4) but are not free of failures (5). In the past, it was often necessary to renew the whole restoration. That was not only expensive and time-consuming but also linked with other disadvantages, like the loss of sound enamel and dentine or the risk of an iatrogenic damage of the pulpal tissue $(1,6-11)$. The minimal invasive repair of a failed restoration is a method to improve the time of survival of an existing restoration by avoiding most of the disadvantages of renewing the whole restoration $(3,8,10,12)$.

It is not recommended to repair every failed composite restoration. The defect has to be visible and possible caries has to be reliably removed (13). As recommended for the use of any adhesive technique the cavity has to be dry. Isolation by rubber dam is recommended but not mandatory if the cavity can be kept relatively dry $(3,13-15)$. There is no standard protocol for repairing a failed restoration $(8,16)$. It is generally agreed that the old composite surface has to be roughened by burs or sandblasting $(8,13,16-19)$, however the created surface roughness does not correlate with the produced bond strengths (20). The effect of the use of a silane solution is problematic. There are on the one hand studies that showed an increase of bond strength by the application of a silane solution (21-23) and on the other hand studies that showed that the use of a silane solution had no effect or even produced lower bond strengths $(19,24)$. The use of a bonding in composite repair is obligatory (25).

The use of a sandblaster for roughening the old composite has the advantage that every surface can easily be reached. Modern air-polishing-powders like glycine or erythritol are less abrasive to oral tissues than salt-based powders like sodium-bicarbonate (2628 ), but the use of a sodium-bicarbonate-powder in composite repair was already proofed to be successful (29). If the less abrasive air-polishing-powders can perform in the same way, it can improve the repair of composite by preventing gingival bleeding, especially if no rubber dam is used, and may help saving tooth tissues.

A larger number of possible set-ups to measure bond strength between two materials was described in literature, however no standardized procedure exists $(30,31)$. Using existing standards for measuring bond strength to tooth structure for repair bond strength measurements seems the best way to avoid a large variation in test parameters. The following standardized bond strength tests are described until now: DIN 13990 (2017) is using a straight blade on orthodontic attachments and ISO 29022 (2013) a notched-edge blade for testing shear bond strength. ISO/TS 11405 (2015) describes a tensile bond strength test. All of them are macro bond tests, because bonding area is greater than $1 \mathrm{~mm}^{2}$ (ISO/TS 11405). By the use of macro shear or macro tensile tests tension peaks will appear in the substrate, however not in the bonding area. This might lead to a high number of cohesive failures and the measured 'bond strength' is the compressive strength of the substrate (32-34). Artificial ageing of bonded specimens is an important factor to assess their long-term behaviour (35). In the current literature there is a high variability of the artificial ageing parameters not only in water temperature and in the number of cycles (36).

It was the aim of this study to investigate whether blasting treatment using a glycine powder can be used successfully in composite repair and to compare different measurement principles of shear and tensile bond strength testing according to dental standards.

\section{Materials and Methods}

\section{Material}

The Repair Bond Strength of Tetric EvoCeram ${ }^{\circledR}$ (Ivoclar Vivadent, Schaan, Liechtenstein) was investigated in this study. Surface roughening was performed by glycine powder (particle size $\sim 25 \mu \mathrm{m}$; AIR-FLOW ${ }^{\circledR}$ Perio, EMS, Le Sentier, Suisse) or aluminium-oxide powder (particle size $~ 50 \mu \mathrm{m}$; Rønvig Dental, Daugaard, Denmark). The materials used in the chemical conditioning were phosphoric acid (Total Etch, Ivoclar Vivadent), a silane solution (Monobond ${ }^{\circledR}$ Plus, Ivoclar Vivadent) and a bonding agent (Heliobond, Ivoclar Vivadent). The investigated materials are summarized in Table 1.

Table 1. Overview of the materials investigated in this study.

\begin{tabular}{|c|c|c|}
\hline Product & Manufacturer & Use \\
\hline $\begin{array}{l}\text { Tetric } \\
\text { EvoCeram® }\end{array}$ & $\begin{array}{l}\text { Ivoclar } \\
\text { Vivadent }\end{array}$ & Nano-hybrid-composite \\
\hline Total Etch & $\begin{array}{l}\text { Ivoclar } \\
\text { Vivadent }\end{array}$ & $37 \%$ phosphoric acid gel \\
\hline Monobond® Plus & $\begin{array}{l}\text { Ivoclar } \\
\text { Vivadent }\end{array}$ & Silane solution \\
\hline Heliobond & $\begin{array}{l}\text { Ivoclar } \\
\text { Vivadent }\end{array}$ & Bonding agent \\
\hline $\begin{array}{l}\text { AIR-FLOW } \circledast \\
\text { Perio }\end{array}$ & EMS & $\begin{array}{l}\text { glycine powder } \\
\text { Particle size } \sim 25 \mu \mathrm{m}\end{array}$ \\
\hline $\begin{array}{l}\text { Aluminium-oxide } \\
\text { powder }\end{array}$ & Rønvig Dental & $\begin{array}{l}\text { aluminium-oxide powder. } \\
\text { Particle size } \sim 50 \mu \mathrm{m}\end{array}$ \\
\hline
\end{tabular}

The water used for artificial ageing conformed to DIN ISO 3696, Quality 3. The light-curing-unit (LUX LEDMAX 1055, Dentaurum, Ispringen, Germany) was used in "Fast-Mode" that emits light with a wavelength between 460 and $480 \mathrm{~nm}$ and an intensity of 1300 $\mathrm{mW} / \mathrm{cm}^{2}$. It was frequently checked with an integrated photometer if the intensity was above $1000 \mathrm{~mW} / \mathrm{cm}^{2}$ as advised by the composite manufacturer.

\section{Specimen preparation}

540 specimen holders - 180 for each test - with a hole with a diameter of $6 \mathrm{~mm}$ and a depth of $2 \mathrm{~mm}$ were prepared from Technovit ${ }^{\circledR} 4004$ (Kulzer, Hanau, Germany). Tetric EvoCeram $₫$ was filled in the hole, covered with a polyester strip (Hawe ${ }^{T M}$ Transparent Strips, Kerr, Orange, CA) and flattened with a glass plate. The composite substrate was first light cured 
through the glass plate for 10 seconds, then the plate was removed and the composite was light cured again for 10 seconds. All specimens were artificially aged by storage in water for 7 days at $37 \pm 1{ }^{\circ} \mathrm{C}$.

\section{Mechanical preparation}

The 180 specimens of each test group were randomly assigned to one of the following groups for mechanical preparation: Negative control group (no surface roughening), test group (air-polishing by glycine powder) or positive control group (air-abrasion by aluminium-oxide powder). Air-polishing was performed by an air-polishing-unit (AIR-FLOW MASTER ${ }^{\circledR}$, EMS) with glycine powder (AIR-FLOW $®$ Perio) for 10 seconds at a distance of $10 \mathrm{~mm}$ and at an angle of $90^{\circ}$. Air abrasion was done by a sandblasting handpiece (MicroEtcher ${ }^{T M} \mathrm{CD}$, Zest Dental Solutions, Carlsbad, CA) on a dental unit (KAVO Systematica, KaVo, Biberach, Germany, ) for 5 seconds at a distance of $10 \mathrm{~mm}$ and at an angle of $90^{\circ}$.

\section{Chemical conditioning}

60 specimens per group were randomly assigned again to one of the three following groups: a) Bonding group (Bond), b) phosphoric acid and bonding group (PA+Bond) or c) phosphoric acid, silane solution and bonding group (PA+Sil+Bond). Phosphoric acid (Total Etch) was applied to the surfaces for 20 seconds, rinsed with water and dried. The silane solution (Monobond ${ }^{\circledR}$ Plus) was applied for 60 seconds and excesses were dried with air. The bonding agent (Heliobond) was applied for 20 seconds, thinned with air and light cured for 10 seconds.

\section{Shear Bond test according to DIN 13990 (2017)}

For shear bond testing according to DIN 13990 (2017) a transparent silicone perforated disc (visio.sil, Bredent, Senden, Germany) with an inner diameter of $3 \mathrm{~mm}$ was placed on top of the composite substrate and a small amount of fresh composite was applied in the hole. It was packed with a plugger and light cured for 10 seconds before the silicone disc was removed while fixating the repair composite with a plugger.

\section{Shear Bond test according to ISO 29022 (2013)}

The repair composite application for shear bond testing according to ISO 29022 was similar to the shear bond test according to DIN 13990 (2017) but a bonding clamp with a teflon button mould insert with an inner diameter of $2.38 \mathrm{~mm}$ was used. The repair composite was applied, light-cured for 10 seconds and the button mould was removed as before.

\section{Tensile Bond test according to ISO/TS 11405 (2015)}

For the tensile bond test metal hulls with two lateral windows were used. One end of the hull was a circle with a diameter of $4 \mathrm{~mm}$, the other end was a screw thread. The hull was placed with the $4 \mathrm{~mm}$ hole on the composite substrate and fixed with a clamp. Repair composite was placed and light cured for 5 seconds through each lateral window.

\section{Artificial ageing of the bonding interface}

According to DIN/ISO artificial ageing of the bonding interface was performed by water storage at $37 \pm 2{ }^{\circ} \mathrm{C}$ for $24 \pm 2 \mathrm{~h}$ (group water) or a water storage at $37 \pm 2{ }^{\circ} \mathrm{C}$ for $24 \pm 2 \mathrm{~h}$ followed by a thermocycling of 500 cycles between $5{ }^{\circ} \mathrm{C}$ and $55{ }^{\circ} \mathrm{C}$ for 30 seconds (group TC). The 20 bonded specimens per group were assigned randomly to one of the two artificial ageing groups before assessing the bond strength test.

\section{Bond tests}

After artificial ageing the specimens were assigned to their corresponding bond test. An overview over some parameters of the different test methods are summarized in table 2 . The specimens of the shear bond test according to DIN 13990 (2017) were fixed in a shear guillotine and the blade was carefully placed on top of the repair composite, as close as possible to the substrate surface (Figure 1a).

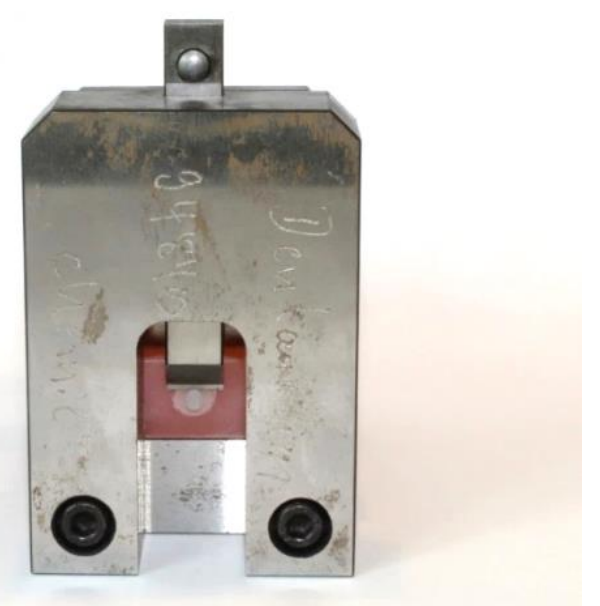

Figure 1a. Setup for the shear bond test according to DIN 13990. The specimen is mounted to a shear guillotine.

Table 2. Overview of the standards and their parameters tested in the study.

\begin{tabular}{|c|c|c|c|}
\hline Norm & $\begin{array}{c}\text { DIN } \\
13990\end{array}$ & ISO 29022 & $\begin{array}{c}\text { ISO/TS } \\
11405\end{array}$ \\
\hline Load modus & $\begin{array}{c}\text { Shear test } \\
\text { Straight } \\
\text { blade }\end{array}$ & $\begin{array}{c}\text { Shear test } \\
\text { Notched-edge } \\
\text { blade }\end{array}$ & Tensile test \\
\hline $\begin{array}{l}\text { Bonding area } \\
\text { Diameter in } \\
\mathrm{mm}\end{array}$ & 3.00 & 2.38 & Not specified \\
\hline $\begin{array}{l}\text { Bonding area } \\
\text { Surface in } \\
\mathrm{mm}^{2}\end{array}$ & 7.07 & 4.45 & Not specified \\
\hline $\begin{array}{l}\text { Crosshead } \\
\text { speed in } \\
\mathrm{mm} / \mathrm{min}\end{array}$ & $1.0 \pm 0.1$ & $1.0 \pm 0.1$ & $0.75 \pm 0.30$ \\
\hline
\end{tabular}


The shear guillotine we used for shear bond testing with a straight blade is described in ISO 10477 (2018) but worked with parameters according to DIN 13990 (2017). The guillotine was placed in an universal testing machine (Zmart.Pro, ZwickRoell, Ulm, Germany) and loaded with a crosshead speed of $1 \mathrm{~mm} / \mathrm{min}$ until fracture. The specimens of the shear bond test according to ISO 29022 (2013) were fixed in a test base clamp and placed in the universal testing machine (Figure 1b). The notched-edge shear blade was positioned in the way that the repair resin cylinder just fitted in the notched edge and specimens were loaded with a crosshead speed of $1 \mathrm{~mm} / \mathrm{min}$.

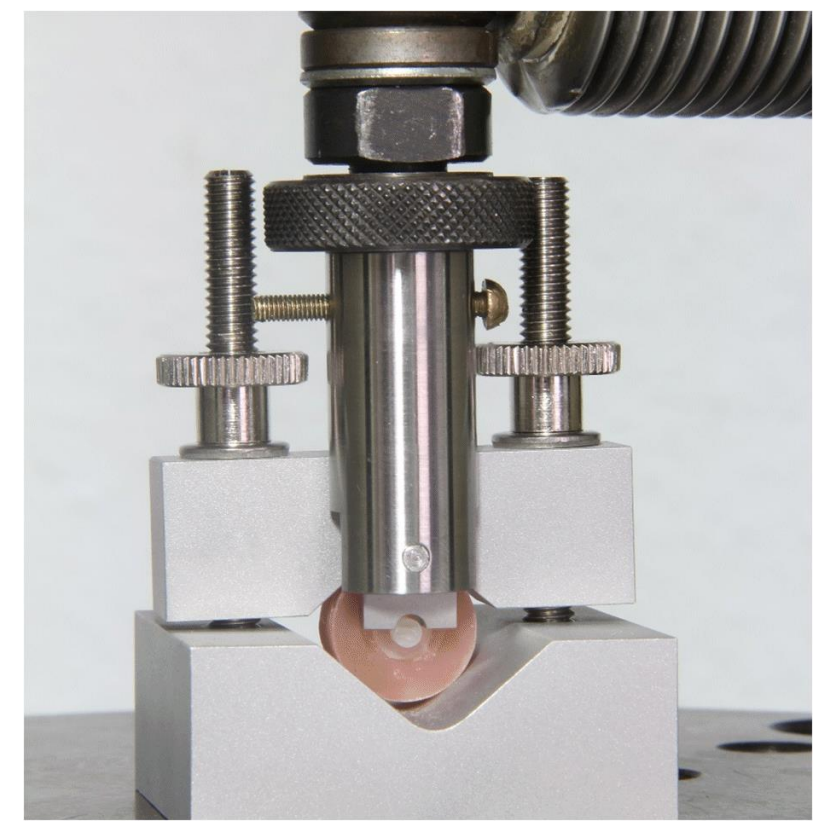

Figure $1 \mathrm{~b}$. Setup for the shear bond test according to ISO 29022. The specimen is mounted in a test base clamp and directly fitted into the notched-edge of the shear blade.

For the tensile bond strength test the metal hull was placed through a perforated metal plate that was fixed in the universal testing machine. The thread of the hull was screwed to a hook at the other end of the testing machine so that the specimen holder worked as an abutment (Figure 1c). The tensile speed was 1 $\mathrm{mm} / \mathrm{min}$ as before. The test-software (testXpert $\circledast \mathrm{II}, \mathrm{V}$ 3.0, ZwickRoell) recorded a force-displacement diagram and the maximum force for each specimen. Maximum tension was calculated by maximum force divided by the bonding area. Specimens that failed during artificial ageing were noted as $0 \mathrm{MPa}$.

\section{Analysis of fracture modes}

The fracture mode for each specimen was examined under a stereo-microscope at 12-times magnification. Fracture modes were classified by adhesive fracture if only the bonding interface failed, cohesive fracture if the substrate or repair composite failed or mixed fracture if there was a combination of adhesive and cohesive failure. Specimens that failed during artificial ageing were not included in the analysis of fracture modes.

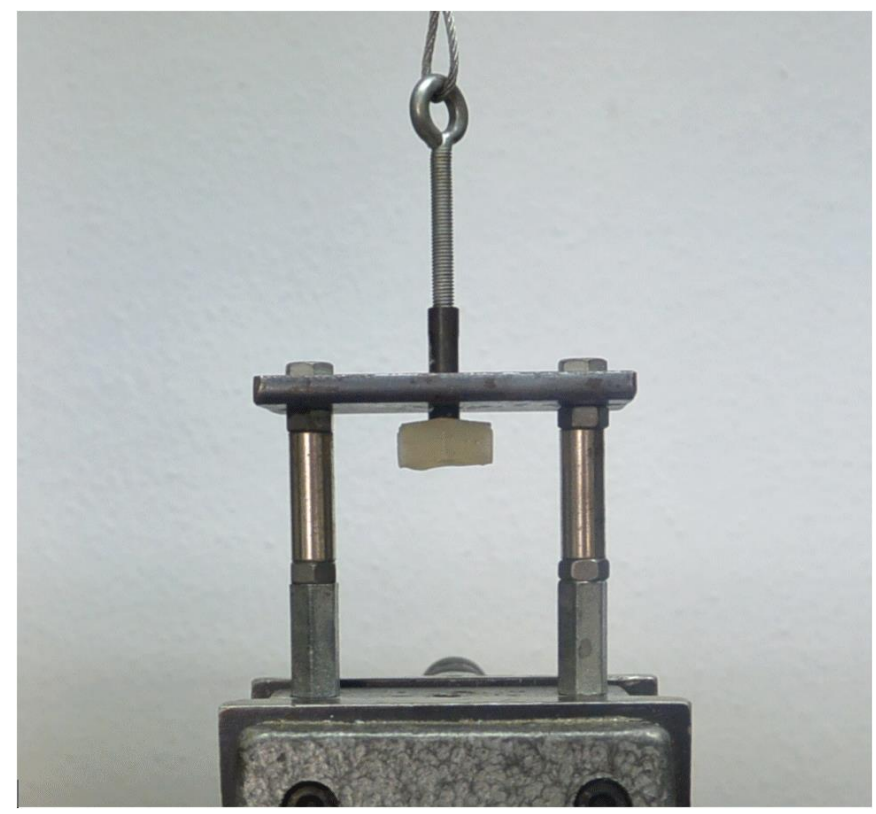

Figure 1c. Setup for the tensile bond test according to ISO/TS 11405 . The metal hull with the repair-composite is threaded to a hook and the specimen holder with the composite substrate functions as an abutment.

\section{Statistical Analysis}

The measured bond strength values were tested on homogeneity of variances between the three investigated tests by Levene-Test. Normal-distribution was tested group-wise by Shapiro-Wilk-test. Statistical analysis of bond strength between the three investigated tests was performed by the nonparametric Kruskall-Wallis-Test with pair-wise comparison by Mann-Whitney-U-Test. The influence of the mechanical preparation, chemical conditioning and artificial ageing was investigated by a generalized linear model. The distribution of the fracture modes was analysed by Chi-Square-Test. All statistical tests were performed with a significance level of $5 \%$.

\section{Results}

\section{Bond strength test}

The bond strength values of the shear test according to DIN 13990 (2017) were the highest $(26.0 \pm 8.9 \mathrm{MPa})$, followed by the notched-edge shear bond test $(17.9 \pm 6.3 \mathrm{MPa})$ and the tensile bond test $(6.9 \pm 1.8 \mathrm{MPa})$. All bond strength values were significantly different from each other $(p<0.05)$. Medium bond strength values of the bond strength test are shown in Graphic 1. There was no consistent significant influence of the mechanical or chemical preparation Table 3). 


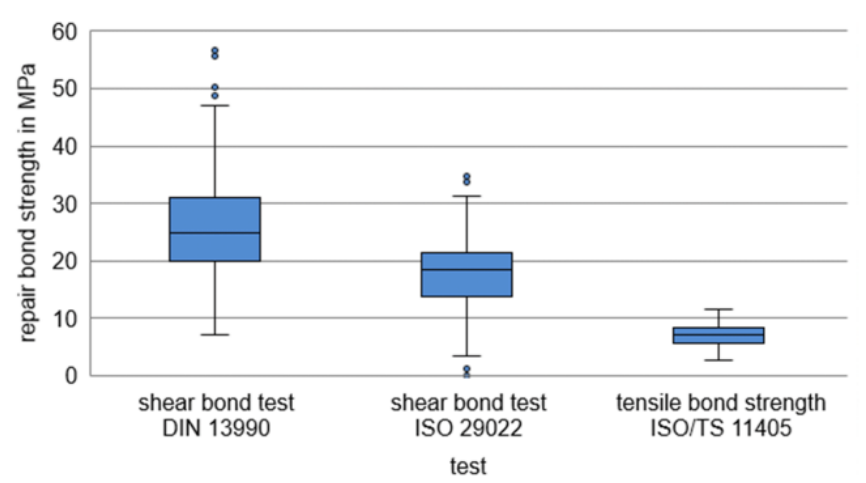

Graphic 1. Box-plot-diagrams of the repair bond strength in the 3 different tested norms. Shear bond strength according to DIN 13990 is the highest, followed by the shear bond strength according to ISO 29022 and the tensile bond strength according to ISO/TS 11405.

Table 3. Statistical influence of test parameters on the measured bond strength values.

\begin{tabular}{|c|c|c|c|}
\hline test & $\begin{array}{l}\text { mechanical } \\
\text { preparation }\end{array}$ & $\begin{array}{l}\text { chemical } \\
\text { conditioning }\end{array}$ & $\begin{array}{l}\text { artificial } \\
\text { ageing }\end{array}$ \\
\hline $\begin{array}{l}\text { DIN } \\
13990\end{array}$ & $p=0.206$ & $p=0.168$ & $p=0.631$ \\
\hline ISO 29022 & $p=0.596$ & $p=0.678$ & $p=0.011$ \\
\hline $\begin{array}{l}\text { ISO/TS } \\
11405\end{array}$ & $p=0.038$ & $p=0.048$ & $p=0.318$ \\
\hline
\end{tabular}

The tensile bond strength test according to ISO/TS 11405 (2015) showed that there is a statistically significant influence of the mechanical and chemical treatment that could not be proofed within the other tests. The statistical analysis of the parameters of the shear bond test according to ISO 29022 (2013) showed a statistically significant influence of the artificial ageing, however the other tests did not. Graphical analysis for artificial ageing at the shear bond test according to ISO 29022 (2013) showed a several outliers and long whiskers (Graphic 2a).

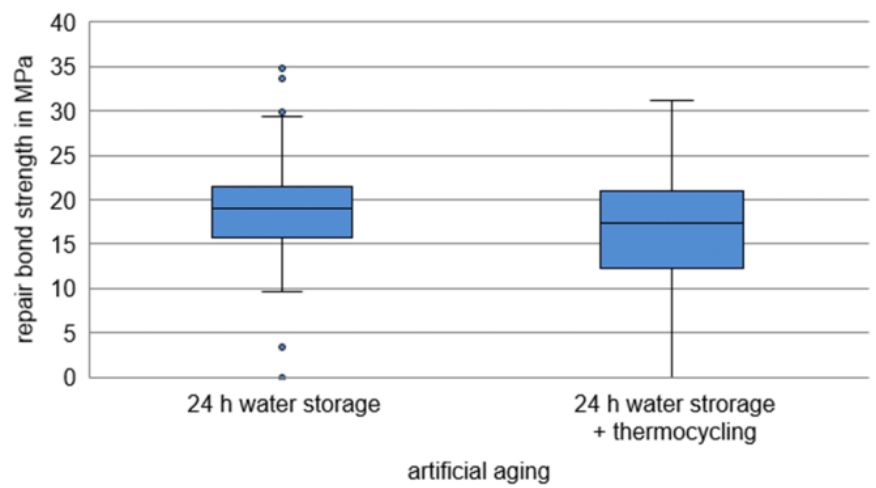

Graphic 2a. Box-plot-diagram of the influence of artificial ageing on the repair bond strength of the shear bond strength test according to ISO 29022. As opposed to the statistical analysis by a generalized linear model the graphical analysis does not reveal an influence of artificial ageing. There are several outliers that maybe affect the statistical analysis in the $24 \mathrm{~h}$ water storage group and a long whisker reaching to zero at the thermocycling group.
Box-plot-diagrams for the mechanical preparation and chemical conditioning within the tensile bond strength test according to ISO/TS 11405 (2015) are shown in Graphic $2 \mathrm{~b}$ and $2 \mathrm{c}$ and do not show an influence of the mechanical or chemical pretreatment on the measured bond strength values.

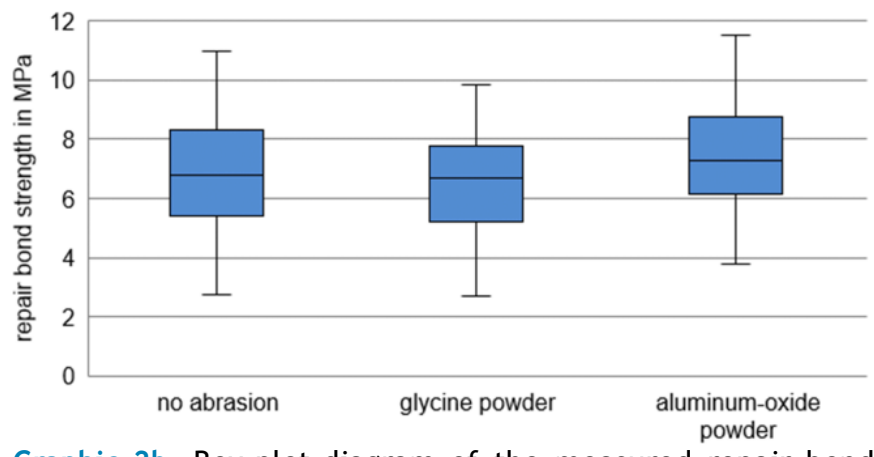

Graphic 2b. Box-plot-diagram of the measured repair bond strength values in the tensile bond strength test according to ISO/TS 11405. Boxes and Whiskers overlap and do not reveal a influence of mechanical preparation on the bond strength values.

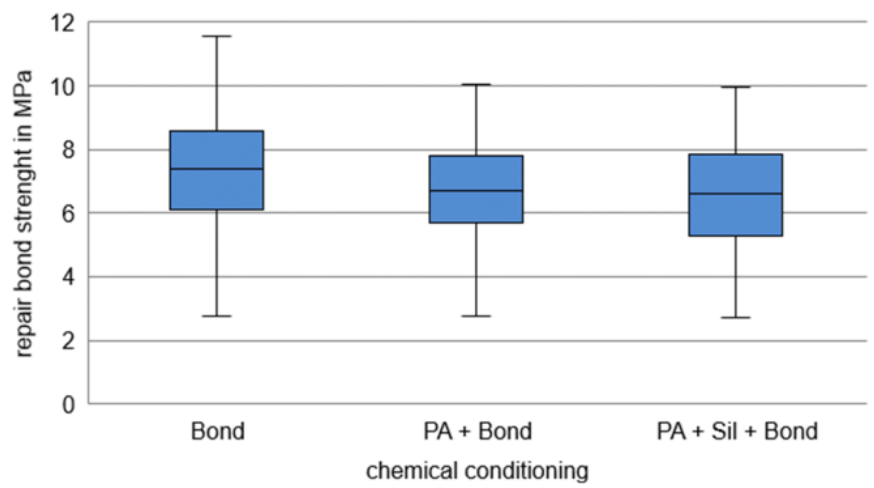

Graphic 2c. Box-plot-diagram if the influence of the chemical conditioning on the repair bond strength in the tensile bond strength test according to ISO/TS 11405. Because the boxes and whiskers are overlapping a can be reasoned that there is not influence of chemical conditioning on the bond strength values.

\section{Fracture modes}

Depending on the bond strength test, the most adhesive failure occurred with notched edge in shear bond test $(n=73 ; 41 \%)$, followed by the straight blade shear bond test $(n=33 ; 18 \%)$ and the tensile bond test $(n=7 ; 4 \%)$. Distributions are shown in Graphic 3a and were significantly different from each other $(p<0.05)$.

Depending on the mechanical preparations, most of the adhesive fractures occurred in the group without preparation $(n=66 ; 37 \%)$, followed by the glycine powder $(n=31 ; 17 \%)$ and the aluminium-oxide powder $(n=16 ; 9 \%)$. Every group was significantly different from each other $(p<0.05)$. Distributions are shown in Graphic $3 b$. 


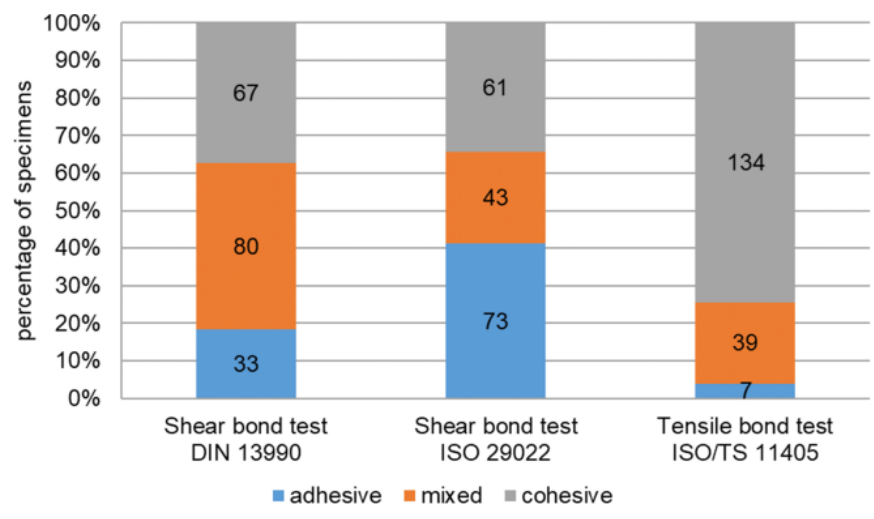

Graphic 3a. Stacked column chart of the distribution of fracture modes in relation to the used bond strength test. The shear test according to ISO 29022 produces the highest part of adhesive failures. The shear test according to DIN 13990 produces the half number of adhesive failures but the highest amount of mixed failures and the tensile bond test according to ISO/TS 11405 produces nearly no adhesive fractures but a very high amount of cohesive fractures.

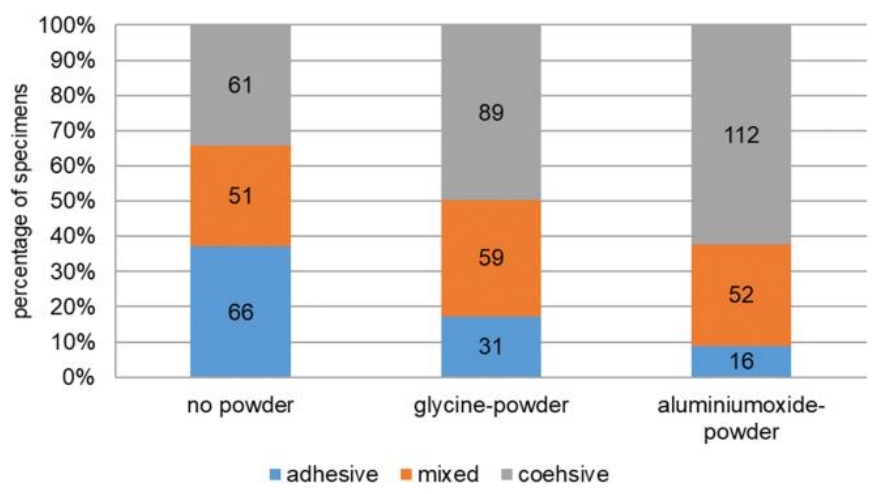

Graphic 3b. Stacked column chart of the distribution of fracture modes in relation to the used mechanical preparation. The use of aluminium-oxide powder leads to the lowest amount of adhesive but the highest of cohesive failures. Using glycine powder produces more adhesive failures and the disclaiming of a surface roughening produces the most adhesive failures.

The influence of chemical preparation was not significant $(p=0.74)$ and is shown in Graphic 3c. The artificial ageing $(\mathrm{p}=0.581)$ had no influence on the distribution of the fracture modes.

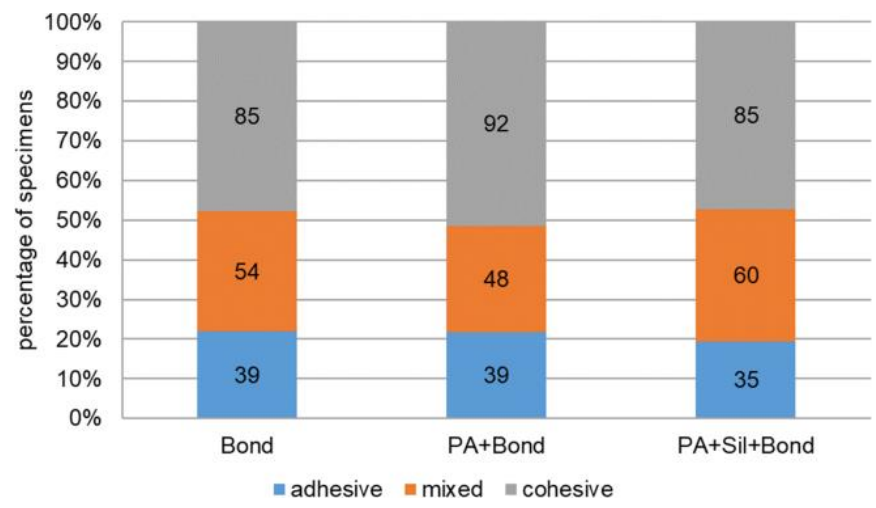

Graphic 3c. Stacked column chart of the distribution of fracture modes in relation to the chemical preparation. The conditioning protocol does not seem to have any effect on the distribution of fracture patterns.

\section{Discussion}

For repair of dental composites a high bond strength between the old composite substrate and the new repair-composite is demanded $(13,16)$. Many authors postulate standardized tests for dental materials $(31,37)$, so the conclusion is to use standards by ISO or DIN for in-vitro studies. The tests described in the standards DIN 13990 (2017), ISO 29022 (2013) and ISO/TS 11405 (2015) are macro-bond-tests with a bonding area greater than $1 \mathrm{~mm}^{2}$ (ISO/TS 11405). These macro-bond-tests are an efficient way to test the bond strength between composite and tooth structure but can be used for measuring the bond strength in composite repair as well. The obvious disadvantages in their test design are tension peaks next to the bonding area that stress the composite substrate much more than the bonding area and may lead to a false interpretation of the results (33). New inventions like the micro-tensile-test (38) showed that measured bond strengths are reciprocally proportional to the bonding area. Unfortunately, they are much more technique sensitive and time-consuming (31) and not mentioned in any standard so far.

The shear bond test according to DIN 13990 (2017) describes debonding of specimens by a pull bow. When investigating bond strength values to a homogeneous composite substrate the orientation of the substrate cannot have an influence on the bond strength values. Thus a shear blade was used instead of the pull bow. All other parameters were kept according to DIN 13990 (2017).

The measured bond strengths have to be interpreted in consideration of the fracture modes (39). Of the three standardized bond-strength-tests only the shear bond test according to ISO 29022 (2013) can be recommended for testing repair bond strength of composites, because the ratio of adhesive failures is the highest of the investigated tests and allows to interpret the performance of the bonding interface and not the substrate.

Analysis of the influence of mechanical preparation or chemical preparation of the composite substrate or artificial ageing of the bonding interface on the repair bond strength did not reveal a consistent significant influence. Artificial ageing by additional 500 cycles does not generate a higher stress on the bonding area than $24 \mathrm{~h}$ water storage alone. Within the limits of the study it can be supposed that the tested nanohybrid-composite is robust to different repair protocols, and the use of an additional intra-oral sandblaster is not necessary for a sufficient repair if the role of plaque on the bond strength is neglected. Further studies are necessary to proof the use of glycine powder in composite repair by more sensitive bond strength tests. Maybe smaller bonding areas can improve the outcomes of shear bond tests according to ISO 29022 (2013). 


\section{Conclusions}

Of the three investigated standards for bond strength testing only the shear bond test according to ISO 29022 (2013) can be recommended for testing repair bond strength. Within the limitation of the study it can be supposed that nano-hybrid-composites are robust for different repair protocols, and the use of glycine powder provides a sufficient adhesion of the bonding agent. An enhancement of the ISO 29022 (2013) with smaller diameters or an insertion of microtensile-testing to ISO/TS 11405 (2015) for testing composite repair bond strength should be investigated and discussed.

Peer-review: Externally peer-reviewed.

Author Contributions: Conception - G.P.H., S.R., C.B.; Design G.P.H., S.R., N.D., A.W., C.B.; Supervision - C.B., S.R.; Materials N.A.; Data Collection and/or Processing - G.P.H., S.R., A.W.; Analysis and/or Interpretation - G.P.H., J.K., S.R., J.N., N.D., C.B.; Literature Review - G.P.H.; Writer - G.P.H., C.B.; Critical Review - N.D., S.R., L.K., A.W., J.N.

Acknowledgments: The authors would like to thank the companies Ivoclar Vivadent, EMS, Ultradent Products and Dentaurum for the friendly provision of dental materials and testing devices.

Conflict of Interest: No conflict of interest was declared by the authors.

Financial Disclosure: The authors declared that this study has received no financial support.

\section{References}

1. Anderson MH. Current concepts of dental caries and its prevention. Oper Dent Supp 2001;6:11-18.

2. Bogacki RE, Hunt RJ, del Aguila M, Smith WR. Survival analysis of posterior restorations using an insurance claims database. Oper Dent 2002;27:488-492.

3. Lynch CD, Opdam NJ, Hickel R, Brunton PA, Gurgan S, Kakaboura A, Shearer AC, Vanherle G, Wilson NH. Guidance on posterior resin composites: Academy of Opera-tive Dentistry European Section. J Dent 2014;42:377-383. (Crossref)

4. Staehle HJ, Wolff D, Frese C. Mehr Zahnerhaltung wagen Langzeitbeobachtungen von direkten Kompositrestaurationen. Quintessenz 2014; 65: 547-555.

5. Opdam NJ, Bronkhorst EM, Loomans BA, Huysmans MC. 12-year survival of composite vs. amalgam restorations. J Dent Res 2010;89:1063-1067. (Crossref)

6. Blum IR, Jagger DC, Wilson HH. Defective dental restorations: to repair or not to repair? Part 1: direct composite restorations. SADJ 2011;66:114-118. (Crossref)

7. Blum IR, Lynch $C D$, Wilson $\mathrm{NH}$. Factors influencing repair of dental restorations with resin composite. Clin Cosmet Investig Dent 2014;6:81-87. (Crossref)

8. Hickel R, Brüshaver K, Ilie N. Repair of restorations - Criteria for decision making and clinical recommendations. Dent Mater 2013;29:28-50. (Crossref)
9. Krejci I, Lieber CM, Lutz F. Time required to remove totally bonded tooth-colored posterior restorations and related tooth substance loss. Dent Mater 1995;11:34-40. (Crossref)

10. Martin J, Fernandez E, Estay J, Gordan VV, Mjor IA, Moncada G. Minimal invasive treatment for defective restorations: fiveyear results using sealants. Oper Dent 2013;38:125-33. (Crossref)

11. Simonsen RJ. Conservation of tooth structure in restorative dentistry. Quintessence Int 1985;16:15-24.

12. Fernandez E, Martin J, Vildosola P, Oliveira Junior OB, Gordan V, Mjor I, Bersezio C, Estay J, de Andrade MF, Moncada G. Can repair increase the longevity of composite resins? Results of a 10-year clinical trial. J Dent 2015;43:279-286. (Crossref)

13. Foitzik M, Attin T. Korrekturfüllung - Möglichkeiten und Durchführung. Schweiz Monatsschr Zahnmed 2004;114:10031011.

14. Staehle HJ. Reparatur zahnärztlicher Restaurationen. Zahnärzteblatt Baden-Württemberg 2011;12:30-32.

15. Winen RG. Kofferdam - Stand des Wissens. Quintessenz 2017; 68: 745-755.

16. Loomans BA, Cardoso MV, Roeters FJ, Opdam NJ, De Munck J, Huysmans MC, van Meerbeek B. Is there one optimal repair technique for all composites? Dent Mater 2011b;27:701-709. (Crossref)

17. Frankenberger R, Krämer N, Ebert J, Lohbauer U, Käppel S, ten Weges $S$, Petschelt A Fatigue behavior of the resin-resin bond of partially replaced resin composite restora-tions. Am J Dent 2003a;16:17-22.

18. Loomans BA, Cardoso MV, Opdam NJ, Roeters FJ, De Munck J, Huysmans MC, van Meerbeek B. Surface roughness of etched composite resin in light of composite repair. J Dent. 2011a;39:499-505. (Crossref)

19. Rathke A, Tymina Y, Haller B. Effect of different surface treatments on the composite-composite repair bond strength. Clin Oral Investig 2009;13:317-323. (Crossref)

20. Wendler M, Belli R, Panzer R, Skibbe D, Petschelt A, Lohbauer U. Repair Bond Strength of Aged Resin Composite after Different Surfcae and Bonding Treatments. Materials (Basel) 2016;9:E547. (Crossref)

21. Eliasson ST, Tibballs J, Dahl JE. Effect of different surface treatments and adhesives on repair bond strength of resin composites after one and 12 months of storage using an improved microtensile test method. Oper Dent 2014; 39: E206216. (Crossref)

22. Fawzy AS, El-Askary FS, Amer MA. Effect of surface treatments on the tensile bond strength of repaired water-aged anterior restorative micro-fine hybrid resin composite. J Dent 2008; 36: 969-976. (Crossref)

23. Özcan M, Pekkan G. Effect of different adhesion strategies on bond strength of resin composite to composite-dentin complex. Oper Dent 2013;38:63-72. (Crossref)

24. Kaneko M, Caldas RA, Teitosa VP, Xediek Consani RL, Schneider LF, Bacchi A. Influ-ence of surface treatments to repair recent fillings of silorane-and methacrylate-based composites. J Conserv Dent 2015;18:424-246. (Crossref)

25. Padipatvuthikul P, Mair LH. Bonding of composite to water aged composite with surface treatments. Dent Mater 2007;23:519. 525. (Crossref)

26. Hägi TT, Hofmänner P, Salvi GE, Ramseier CA, Sculean A. Clinical outcomes following subgingival application of a novel erythritol powder by means of air polishing in sup-portive periodontal therapy: a randomized, controlled clinical study. Quintessenz Int 2013;44:753-761.

27. Hägi TT, Klemensberger $S$, Bereiter R, Nietsche $S$, Cosgarea R, Flury S, Lussi A, Scu-lean A, Eick S. A Biofilm Pocket Model to Evaluate Different Non-Surgical Periodontal Treatment Modalities in Terms of Biofilm Removal and Reformation, Surface Alterations and Attachment of Periodontal Ligament Fibroblasts. PLoS One 2015; 10(6):e0131056. (Crossref) 
28. Petersilka GJ, Bell M, Mehl A, Hickel R, Flemming TF. Root defects following air polish-ing. An in vitro study on the effects of working parameters. J Clin Periodontol 2003;30:165-170. (Crossref)

29. Yesilyurt C, Kusgoz A, Bayram M, Ulker $M$. Initial repair bond strength of a nano-filled hybrid resin: effect of surface treatments and bonding agents. J Esthet Restor Dent 2009;21: 251-260. (Crossref)

30. Braga RR, Meira JB, Boaro LC, Xavier TA. Adhesion to tooth structure: a critical review of "macro" test methods. Dent Mater 2010;26:e38-49. (Crossref)

31. Heintze SD, Zimmerli B. Relevance of in-vitro tests of adhesive and composite dental materials. A review in 3 parts. Part 3: in vitro tests of adhesive systems. Schweiz Monatsschr Zahnmed 2011b;121:1024-1032.

32. Chadwick RG, Mason AG, Sharp W. Attempted evaluation of three porcelain repair systems - what are we really testing? J Oral Rehab 1998;25:610-615. (Crossref)

33. Della Bona A., van Noort R. Shear vs. Tensile Bond Strength of Resin Composite Bonded to Ceramic. J Dent Res 1995;74:151 1596. (Crossref)
34. van Noort R, Noroozi S, Howard IC, Cardew G. A critique of bond strength measure-ments. J Dent 1989;17:61-67. (Crossref)

35. Heintze SD, Zimmerli B. Relevance of in-vitro tests of adhesive and composite dental materials. A review in 3 parts. Part 2: non-standardized tests of composite materials. Schweiz Monatsschr Zahnmed 2011a;121:916-930.

36. Morresi AL, D’Amario M, Capogreco M, Gatto R, Marzo G, D'Arcangelo C, Monaco A. Thermal cycling for restorative materials: does a standardized protocol exist in laboratory testing? A literature review. J Mech Behav Biomed Mater 2014;29:295-308. (Crossref)

37. Heintze SD, Rousson V, Mahn E. Bond strength tests of dental adhesive systems and their correlation with clinical results - A meta-analysis. Dent Mater 2015;31:423-434. (Crossref)

38. Sano H., Shono T., Sonoda H., Takatsu T., Ciucchi B., Carvalho R., Pashley DH. Relationship between surface area for adhesion and tensile bond strength - evaluation of a micro-tensile bond test. Dent Mater 1994;10:236-240. (Crossref)

39. Della Bona A, Anusavice KJ, Mecholsky JJ Jr. Failure analysis of resin composite bonded to ceramic. Dent Mater. 2003;19:693699. (Crossref) 